\title{
Extent of the acute phase response in fulminant hepatic failure
}

\author{
S Izumi, R D Hughes, P G Langley, J R B Pernambuco, Roger Williams
}

\begin{abstract}
The extent of the acute phase response and the relation between acute phase proteins and cytokines in plasma was investigated in 50 patients with fulminant hepatic failure. On admission, $C$ reactive protein was significantly higher in fulminant hepatic failure (median: 12.4 $\mu \mathrm{g} / \mathrm{ml}$, range: $0 \cdot 2-112 \mu \mathrm{g} / \mathrm{ml}$ ) than in 20 controls (median: $0.8 \mu \mathrm{g} / \mathrm{ml}$, range: $0 \cdot 3-2 \cdot 9 \mu \mathrm{g} / \mathrm{ml}, \mathbf{p}<0 \cdot 001)$. Serial measurements showed that plasma $C$ reactive protein increased daily after admission until day 5 , the end of the study period. $\alpha_{1}$-Antitrypsin (AAT) (median: 69.1\%, range: $27 \cdot 5-124 \%$ and fibrinogen (median: $1.10 \mathrm{~g} / \mathrm{l}$, range: $0-2 \cdot 82 \mathrm{~g} / \mathrm{l}$ ) were significantly lower in fulminant hepatic failure on admission than in controls (AAT: median: $126 \%$, range: $75 \cdot 4-149 \%$; fibrinogen: median $2 \cdot 48 \mathrm{~g} / \mathrm{l}$, range: $1 \cdot 82-3.39 \mathrm{~g} /, \mathbf{p}<0.001)$ and did not change subsequently. Both AAT and fibrinogen were maintained at significantly higher concentrations in survivors than in those who did not. Bacterial infection occurred in 23 patients during the course of fulminant hepatic failure, but did not influence the concentrations of these three proteins. Interleukin 6 was significantly higher in fulminant hepatic failure (median: $21.2 \mathrm{pg} / \mathrm{ml}$, range: $0-871 \mathrm{pg} / \mathrm{ml}$ ) than in controls (median: $2.4 \mathrm{pg} / \mathrm{ml}$, range: $1 \cdot 5-8 \cdot 2 \mathrm{pg} / \mathrm{ml}, \mathrm{p}<0 \cdot 001)$. There was a significant correlation between interleukin 6 and the $C$ reactive protein concentrations in patients with viral hepatitis on admission and in all patients 48 hours later, consistent with other evidence that interleukin 6 stimulates synthesis of this acute phase protein.

(Gut 1994; 35: 982-986)
\end{abstract}

Institute of Liver

Studies, King's College Hospital and School of Medicine and

Dentistry, London S Izumi

R D Hughes

P G Langley

J R B Pernambuco

Roger Williams

Correspondence to: Dr Roger Williams, Institute of Liver Studies, King's College School of Medicine and Dentistry, Bessemer Road, London SE5 9PJ.

Accepted for publication 10 November 1993 sensitive and specific marker of the acute phase response, ${ }^{1}$ with the plasma concentration rapidly rising several hundred fold. The physiological role of $\mathrm{C}$ reactive protein is complex and remains unclear, but may include the opsonisation of bacteria, immune complexes, and foreign particles. ${ }^{2}$ Other acute phase proteins with well defined function such as $\alpha_{1}$-antitrypsin (AAT) and fibrinogen only increase up to a maximum of five times their normal values. AAT acts as the most important inhibitor of neutrophil elastase, ${ }^{3}$ and fibrinogen plays a central part in blood coagulation.

In fulminant hepatic failure, there is greatly reduced synthesis of proteins, particularly coagulation factors, by the damaged liver with the result that values of factor $\mathrm{V}$ and prolongation of the prothrombin time can be used as measures of hepatic function. The coagulation inhibitors antithrombin-III (AT-III), ${ }^{4}$ protein $\mathrm{C},{ }^{5}$ protein $\mathrm{S},{ }^{6}$ and heparin cofactor $\mathrm{II}^{6}$ are also reduced in fulminant hepatic failure, as is the protease inhibitor AAT, ${ }^{7}$ although the latter is an acute phase protein. The liver is stimulated to produce the acute phase proteins by cytokines released mainly from activated macrophages such as tumour necrosis factor, ${ }^{8}$ interleukin 1,910 and interleukin $6,1^{11-13}$ although interleukin 6 seems to be the most important regulator of acute phase protein synthesis in humans. ${ }^{14-16}$ The production of all three cytokines has been shown to be increased in fulminant hepatic failure. ${ }^{17-19}$ It is unclear, however, if the liver can still produce an acute phase response in fulminant hepatic failure, with the profound loss of liver synthetic function.

In this study the acute phase proteins $C$ reactive protein, AAT, fibrinogen and, for comparison, antithrombin-III (AT-III) (which is not an acute phase protein) were determined in the plasma of 50 patients with fulminant hepatic failure in relation to the course of the illness, as well as the production of cytokines interleukin 6 and interleukin 1 .

\section{Patients and methods}

Fifty patients with fulminant hepatic failure, as defined by Trey and Davidson, ${ }^{20}$ were studied (male: 19, female: 31 , mean age: 31.7 years, range: $13-60$ ), the causes being paracetamol overdose in 40 patients, viral hepatitis in eight (one hepatitis A, two hepatitis B, one hepatitis $C$, four hepatitis non-A non-B), and adverse drug reaction in two patients (Table I). Twenty six patients were in grade 1 or 2 encephalopathy on admission and 10 of these deteriorated further to grade 3 or 4 encephalopathy. The remaining 24 cases were admitted in grade 3 or 4 encephalopathy. Of these 34 patients with grade 3 or 4 encephalopathy, seven patients had liver transplantation after selection on the basis of poor prognostic criteria as used at King's College 
TABLE I Laboratory parameters in patients with fulminant hepatic failure on admission

\begin{tabular}{|c|c|c|c|c|c|c|}
\hline & $\begin{array}{l}\text { Prothrombin } \\
\text { time (INR) }\end{array}$ & $\begin{array}{l}A S T \\
(I U / l)\end{array}$ & $\begin{array}{l}\text { Bilirubin } \\
(\mu \text { moll })\end{array}$ & $\begin{array}{l}\text { Creatinine } \\
(\mu \text { moll })\end{array}$ & $\begin{array}{l}W B C \\
\left(\times 10^{\circ} /\right)\end{array}$ & $\begin{array}{l}\text { Platelets } \\
\left(\times 10^{9} / l\right)\end{array}$ \\
\hline \multicolumn{7}{|c|}{$\begin{array}{l}\text { Paracetamol overdose } \\
(\mathrm{n}=40)\end{array}$} \\
\hline median & $5 \cdot 3$ & $3152^{\star}$ & $73^{\star}$ & $157^{\star \star}$ & $10 \cdot 2$ & 109 \\
\hline $\begin{array}{l}\text { range } \\
\text { Viral and other } \\
(\mathrm{n}=10)\end{array}$ & $2 \cdot 0-15 \cdot 0$ & $100-15000$ & $38-201$ & $52-688$ & $3 \cdot 7-28 \cdot 1$ & $43-290$ \\
\hline $\begin{array}{l}\text { median } \\
\text { range }\end{array}$ & $\begin{array}{l}3 \cdot 8 \\
2 \cdot 2-15 \cdot 0\end{array}$ & $\begin{array}{l}259 \\
93-974\end{array}$ & $\begin{array}{l}270 \\
60-563\end{array}$ & $\begin{array}{l}80 \cdot 0 \\
53-164\end{array}$ & $\begin{array}{l}9 \cdot 2 \\
5 \cdot 8-23 \cdot 2\end{array}$ & $\begin{array}{l}181 \\
35-302\end{array}$ \\
\hline Normal range & $0 \cdot 9-1 \cdot 2$ & $10-50$ & $3-20$ & 45-105 & $5-9$ & $150-400$ \\
\hline
\end{tabular}

AST $=$ serum aspartate aminotransferase; $\mathrm{WBC}=$ white blood cell counts; $\mathrm{INR}=$ international normalised ratio. ${ }^{\star} \mathrm{p}<0.001$, ${ }_{\star \star} \mathrm{p}<0 \cdot 01$.

Hospital. ${ }^{21}$ Of the 43 patients with fulminant hepatic failure who did not receive a liver transplantation, 23 patients survived and 20 patients died. Ten patients received haemodialysis for renal failure. Only one patient received transfusion of fresh frozen plasma because of coagulation abnormality, plasma exchange was only performed for patients about to have transplantation.

Infection was suspected when the axillary temperature exceeded $38^{\circ} \mathrm{C}$ on two successive four hour readings and a peripheral blood leucocyte count exceeded $15 \times 10^{9} / 1$, and diagnosis was confirmed by microbiological examination of blood, urine, and sputum, or from radiological signs of pulmonary consolidation. Eighteen patients had some evidence of infection and five other patients were suspected of infection during the course of admission.

Control samples were obtained from 20 laboratory staff (male: 10, female: 10, mean age: $31 \cdot 8$ years, range: $24-42$ ).

Blood samples were taken on admission and then daily until prothrombin time had returned to normal, death or liver transplantation, to a maximum of five days. In the nonsurvivor group, eight patients were available for study on day 5 . Citrated blood samples were collected on ice and immediately centrifuged for 10 minutes at $2000 \mathrm{~g}$ at $4^{\circ} \mathrm{C}$. The resulting plasma was stored in aliquots at $-70^{\circ} \mathrm{C}$ until assay.
Approval for the study was obtained from the local research ethics committee.

ASSAYS

$C$ reactive protein was assayed by an enzyme linked immunosorbent assay (ELISA) based on the method of Highton. ${ }^{22}$ Anti-serum, peroxidase conjugated anti-serum, and $C$ reactive protein standard were obtained from Dako Ltd (High Wycombe, UK). Microelisa plates (Dynatech, Billingshurst, UK) were coated with antibody to $\mathrm{C}$ reactive protein (diluted 1:5000 in barbitone buffer $\mathrm{pH} 8 \cdot 8$ ) by incubation overnight. Serum samples were diluted (1:1000 and 1:10000) in phosphate buffered saline $\mathrm{pH} 7.4$ containing $0.05 \%$ Tween and $0 \cdot 1 \%$ bovine serum albumin. The peroxidase substrate was $3,5^{\prime}, 5,5^{\prime}$ tetramethyl benzidine in citrate/acetate buffer $\mathrm{pH} 6.0$. A standard curve was run on each plate and all samples were measured in duplicate. The final colour change was measured at $450 \mathrm{~nm}$ using a MR-5000 microplate reader (Dynatech, Billingshurst, UK).

AAT activity was determined using an indirect chromogenic substrate assay (Quadratech, Epsom, UK). Plasma was initially diluted in buffer containing methylamine to degrade $\alpha_{2}$-macroglobulin. AT-III was measured by an indirect chromogenic substrate method (Behring, Hounslow, UK) in which thrombin was added to diluted plasma. The thrombin activity remaining after

TABLE II Values of acute phase proteins and related parameters in patients with fulminant hepatic failure on admission

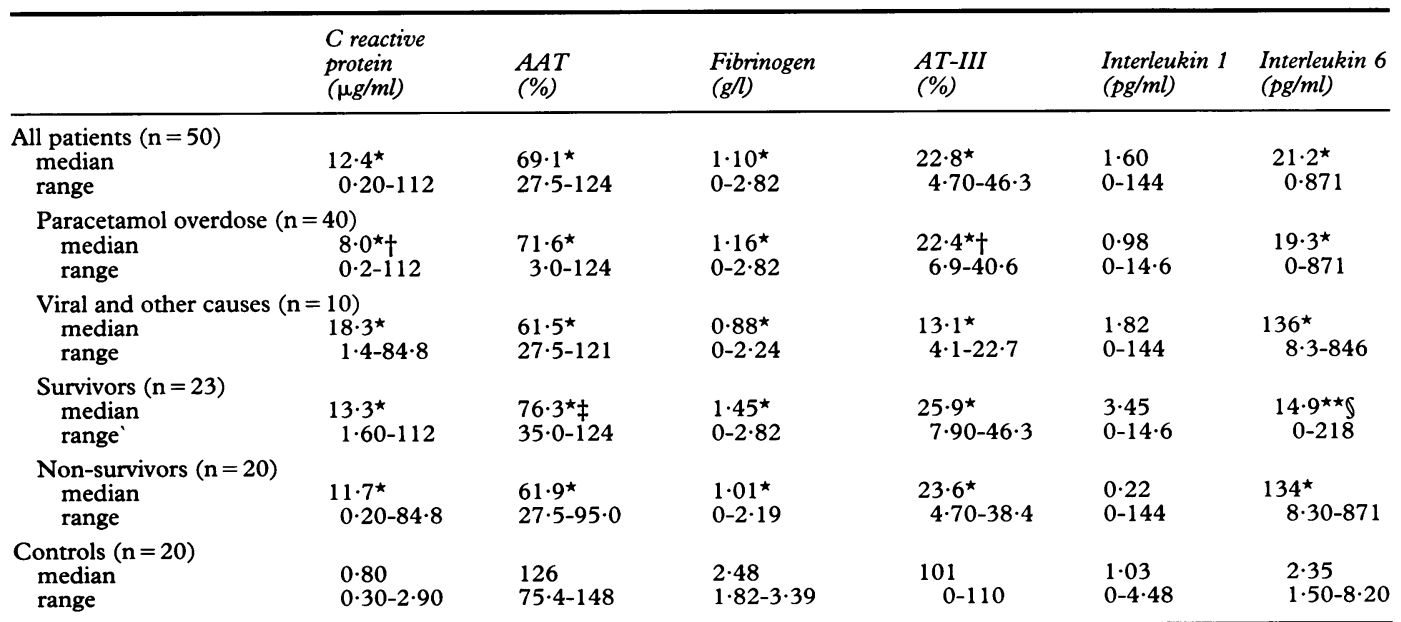

AAT $=\alpha_{1}$-antitrypsin, AT-III $=$ antithrombin-III. ${ }^{\star} \mathrm{p}<0.001,{ }^{\star \star} \mathrm{p}<0.01 v$ controls, $\mathrm{tp}<0.05 v$ viral and other causes, $\neq \mathrm{p}<0.05$, and $\mathrm{Sp}<0.001 v$ non-survivors. 


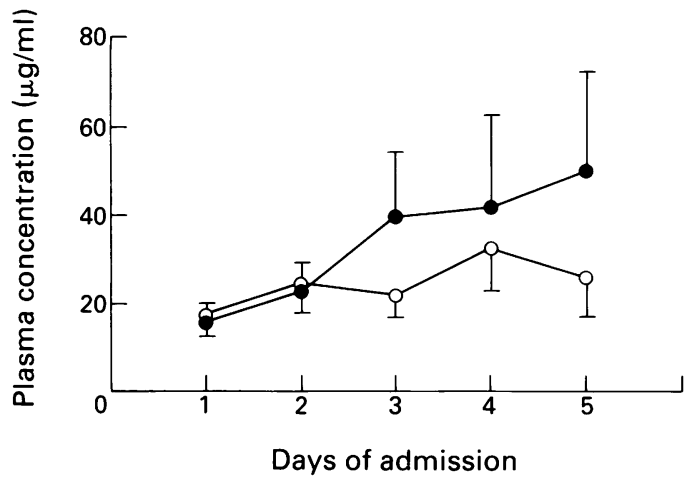

Figure 1: Serial plasma concentrations of $C$ reactive protein in patients with fulminant hepatic failure. Open circles: survivors, filled circles: non-survivors. (Mean (SEM))

incubation gave the AT-III activity in the plasma. The colour change was measured at $405 \mathrm{~nm}$ using a Ultrospec III spectrophotometer (Pharmacia LKB, Milton Keynes, UK). Fibrinogen was measured by the method of Clauss $^{23}$ using a Fibrintimer (Behring, Hounslow, UK). Interleukin 6 was measured by the quantitative 'sandwich' enzyme immunoassay, Quantikine Human interleukin 6 Immunoassay obtained from British Biotechnology Products (Abingdon, UK). This uses a monoclonal antibody specific for interleukin 6 coated onto a microtitre plate. Interleukin 1 was assayed by ACE enzyme immunoassay based on a double antibody 'sandwich' technique kindly supplied by SPI BIO (Saclay, France).

\section{ANALYSIS}

Significance was assessed within groups with analysis of variance and between groups using the Mann-Whitney $U$ test. Correlation between variables was assessed by the Spearman rank correlation coefficient. Results are reported as median and range. Mean (SEM) is shown in the Figures.

\section{Results}

Plasma $\mathrm{C}$ reactive protein on admission was significantly increased compared with control subjects (Table II). Concentrations were significantly higher in patients with fulminant hepatic failure resulting from viral hepatitis and causes other than paracetamol overdose (Table II). There were no significant differences in $C$ reactive protein concentrations between survivors and non-survivors (Table II) or between 23 patients with and 27 without bacterial infection. Plasma $\mathrm{C}$ reactive protein during the course of the illness was in general higher in non-survivors than in survivors from day 3 to day 5 (the end of the study period), although this did not reach statistical significance (Fig 1). Patients who received a liver transplant are not included in any serial data.

Plasma AAT on admission was significantly lower in fulminant hepatic failure than in controls (Table II). Although plasma concentrations of AAT were significantly higher in survivors than in non-survivors, the concentrations even in survivors were significantly lower than in controls (Table II). Plasma AAT was

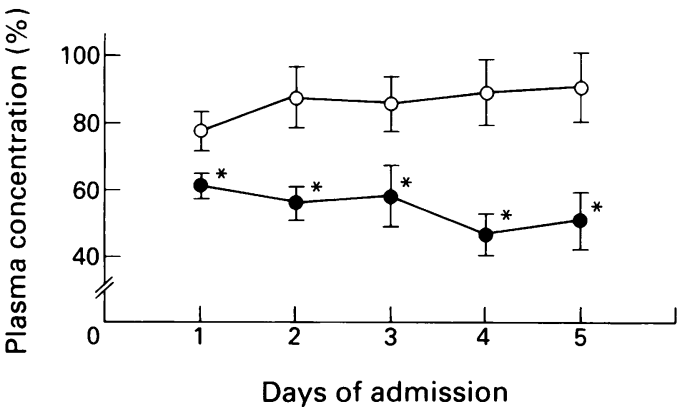

Figure 2: Serial plasma concentrations of $\alpha_{1}$-antitrypsin in patients with fulminant hepatic failure. Open circles: survivors, filled circles: non-survivors. (Mean (SEM)). ${ }^{*} p<0.05$; significant differences between survivors and non-survivors, Mann-Whitney $U$ test.

less reduced than another protease inhibitor AT-III, which is not an acute phase protein, and AT-III was also significantly lower in fulminant hepatic failure than in controls (Table II). There were no significant differences in plasma AAT between patients with and without bacterial infection, or between patients with fulminant hepatic failure resulting from paracetamol overdose and viral hepatitis and other causes (Table II). The serial plasma concentrations of AAT did not change after admission. AAT remained at significantly $(p<0.05)$ higher concentrations in survivors than in non-survivors over the five days of study, and was maintained at more than $70 \%$ of normal (Fig 2). In contrast with AAT, plasma AT-III in the overall fulminant hepatic failure group continued to decrease from the admission value to $10 \cdot 3 \%$ of normal.

Plasma fibrinogen on admission was also significantly lower in fulminant hepatic failure than in controls (Table II). There were no significant differences between patients with and without bacterial infection, or between patients with fulminant hepatic failure resulting from paracetamol overdose and viral hepatitis and other causes or between survivors and non-survivors (Table II). Serial plasma concentrations of fibrinogen did not change after admission. Survivors continued to have significantly higher fibrinogen concentrations than non-survivors from day 2 to day 5 and the values were maintained at more than $1.2 \mathrm{~g} / \mathrm{l}$.

\section{CYTOKINE CONCENTRATIONS AND} CORRELATIONS WITH ACUTE PHASE PROTEINS On admission, plasma interleukin 6 was significantly higher in patients with fulminant hepatic failure than in controls (Table II). Concentrations were significantly higher in patients who did not survive than in survivors (Table II), and no patient survived with an interleukin 6 concentration of more than $300 \mathrm{pg} / \mathrm{ml}$. The pattern of interleukin 6 concentrations in fulminant hepatic failure did not change after admission. Interleukin 6 in nonsurvivors continued to be at significantly higher values than in survivors (day 2 and day $3 ; p<0.001$ and $p<0.05$ ) (Fig 3). There was no significant difference in interleukin 6 concentrations on admission between patients with and without bacterial infection. There 


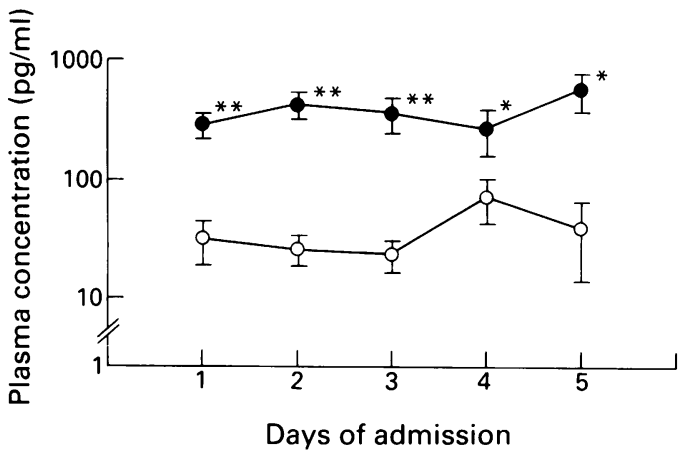

Figure 3: Serial plasma concentrations of interleukin 6 in patients with fulminant hepatic failure. Open circles: survivors, filled circles: non-survivors. (Mean (SEM)). ${ }^{*}{ }^{*}<0.001,{ }^{*} p<0.05 ;$ significant differences between survivors and non-survivors, Mann-Whitney $U$ test.

was also no significant difference between patients with fulminant hepatic failure resulting from paracetamol overdose and viral hepatitis and other causes on admission.

Plasma interleukin 1 concentrations on admission were not significantly different between patients with fulminant hepatic failure and controls, between survivors and nonsurvivors, between patients with and without bacterial infection or between patients with fulminant hepatic failure resulting from paracetamol overdose and viral hepatitis and other causes (Table II). Both patients whose interleukin 1 concentrations were more than $20 \mathrm{pg} / \mathrm{ml}(24.4$ and $144 \mathrm{pg} / \mathrm{ml})$ had fulminant hepatic failure resulting from hepatitis $B$ virus infection.

The correlation between interleukin 6 and $C$ reactive protein on admission was significant in the patients with fulminant hepatic failure resulting from viral hepatitis $(r=0.883, \mathrm{n}=8$, $\mathrm{p}=0.004)$ but not in the paracetamol overdose patients $(r=-0 \cdot 105)$. There was a correlation in all patients between interleukin 6 on admission and plasma $C$ reactive protein 48 hours later $(r=0.410, \mathrm{n}=27, \mathrm{p}=0.034)$.

Interleukin 6 on admission correlated inversely with AAT $(r=-0.414, \mathrm{n}=38$, $\mathrm{p}=0.010)$ and with fibrinogen $(r=-0.370$, $\mathrm{n}=38, \mathrm{p}=0.022$ ) concentrations 24 hours later. Interleukin 6 correlated significantly with prothrombin time $(r=0.291, \mathrm{n}=47$, $\mathrm{p}=0.048$ ) on admission. Plasma interleukin 1 correlated significantly with fibrinogen on admission $(r=0.56, \mathrm{n}=28, \mathrm{p}=0.002)$, but not with the other acute phase proteins or interleukin 6 .

\section{Discussion}

These results show that an acute phase response occurs in fulminant hepatic failure with an increase in plasma $C$ reactive protein and maintenance of higher than expected plasma concentrations of AAT and fibrinogen. In sepsis or trauma, plasma $C$ reactive protein rises rapidly to a maximum of 1000 times its normal low concentration. In this study plasma C reactive protein concentrations were increased by a factor of only 15 compared with control values, showing that the extent of the acute phase response is quite limited in fulminant hepatic failure compared with other acute clinical situations. The response seen was similar irrespective of whether the cause was viral hepatitis infection or paracetamol overdose. Viral infection is not as strong a stimulus for $\mathrm{C}$ reactive protein production as bacterial infection. ${ }^{124}$ The second is common in fulminant hepatic failure, ${ }^{25}$ but in our study there was no difference in $\mathrm{C}$ reactive protein values between patients with complicating bacterial infections and those without. In fulminant hepatic failure, $\mathrm{C}$ reactive protein production may already be at a maximal rate, being limited by the severe loss of hepatic synthetic function as part of the inflammatory response to liver cell injury. Further increase may not be possible even with the added stimulus of bacterial infection, as seen in our patients. Studies of patients with severe sepsis without liver failure have shown that $\mathrm{C}$ reactive protein values are significantly higher in nonsurvivors than in survivors, ${ }^{26}$ but in this study of patients with fulminant hepatic failure there was no statistically significant difference between plasma $\mathrm{C}$ reactive protein values in survivors and non-survivors.

In the patients with fulminant hepatic failure, AAT and fibrinogen were decreased on admission to 69 and $45 \%$ of normal values respectively. The higher AAT and fibrinogen concentrations found in the survivors suggests that the prognosis is poor for those patients who cannot maintain both AAT and fibrinogen during the course of fulminant hepatic failure, although there was some overlap between the two groups. Whether the decrease in values of the two proteins is also because of their increased consumption is not clear. There is evidence for the latter in that increased values of elastase-AAT complexes are found in fulminant hepatic failure ${ }^{7}$ and thus AAT, which is the major inhibitor of elastase released from activated neutrophils, is consumed in this process. Similarly, disseminated intravascular coagulation, which consumes fibrinogen, occurs in patients with fulminant hepatic failure. ${ }^{27} 28$ In this study the concentrations of AAT and fibrinogen were greater than those of ATIII (23\%), which is also synthesised in the liver but is not an acute phase protein. This suggests that despite the lower than normal concentrations of AAT and fibrinogen, there is a comparative increase in synthesis of these proteins compared with ATIII; differences in their rates of consumption could also be a factor in this. It would be difficult to determine accurately the turnover of the individual proteins in an unstable condition such as fulminant hepatic failure.

Interleukin 6 is known to be an important regulator of acute phase protein synthesis in humans. ${ }^{14-16}$ Concentrations of interleukin 6 were found to be increased in patients with fulminant hepatic failure on admission to the intensive care unit. The cause of the increased interleukin 6 production is not clear, but was not related to the presence of bacterial infection and thus probably does not result from endotoxin. It may be an inflammatory response to massive cellular injury, involving 
Kupffer and endothelial cells in the liver. ${ }^{29}$ In septic shock, interleukin 6 production peaked near the onset of sepsis and rapidly decreased to undetectable values within about 24 hours. ${ }^{30}$ The persistence of interleukin 6 in fulminant hepatic failure could point to decreased clearance as an additional factor. The lack of correlation between plasma interleukin 6 and serum creatinine would support the liver as being the main site of clearance of interleukin 6 , as previously reported. ${ }^{31}$ We found no evidence of increased plasma interleukin 1 in this study, although in an earlier study increased interleukin 1 and tumour necrosis factor production were found with fulminant hepatic failure mononuclear cells in vitro. ${ }^{19}$

In keeping with interleukin 6 being a stimulator of the acute phase response, a significant correlation between plasma interleukin 6 and $C$ reactive protein has been described after surgery, ${ }^{32} 33$ in kidney rejection, ${ }^{34}$ and in acute pancreatitis. ${ }^{35}$ Peak values of interleukin 6 were found at two to four hours after an endotoxin challenge in humans and this was associated with a rise in circulating $\mathrm{C}$ reactive protein concentrations 24 hours after the endotoxin bolus. ${ }^{36}$ Similarly, after surgery maximum interleukin 6 values are attained 12 to 24 hours earlier than those of $\mathrm{C}$ reactive protein. ${ }^{32}$ In this study, interleukin 6 correlated with plasma C reactive protein in the small group of patients with fulminant viral hepatitis on admission, and in all patients 48 hours later in the course of fulminant hepatic failure, showing that $\mathrm{C}$ reactive protein synthesis in fulminant hepatic failure could also be the result of the prior increase in interleukin 6 concentrations.

Thus, in fulminant hepatic failure a strong stimulus is present for the acute phase response, but because of the severely reduced hepatic function only limited protein synthesis occurs. The ability of the liver to maintain a response sufficient to overcome increased consumption of the acute phase proteins may be an important protective mechanism.

SI was a visiting clinical research fellow from the Department of Internal Medicine of Hyogo Prefectural Nishinomiya Hospital linked with The Second Department of Internal Medicine, Osaka University Medical School, Japan. This study was presented in part as an abstract at the British Society of Gastroenterology Meeting, University of Warwick, September 1992.

1 Whicher JT, Evans SW. Acute phase proteins. Hospital Update 1990; 16: 899-905.

2 Kolb-Bachofen V. A review on the biological properties of C-reactive protein. Immunobiology 1991; 183: 133-45.

3 Ohlsson K, Olsson I. Neutral proteases of human granulocytes (III). Interaction between human granulocyte elastase and plasma protease inhibitors. Scand f Clin Lab elastase and plasma prote

4 Duckert F. Behaviour of antithrombin III in liver disease. Scand $\mathcal{F}$ Gastroenterol 1973; 8 (suppl 19): 109-12.

5 Langley PG, Williams R. The effect of fulminant hepatic failure on protein $\mathrm{C}$ antigen and activity. Thromb Haemost 1985; 53: 268-72.

6 Langley PG, Williams R. Physiological inhibitors of coagulation in fulminant hepatic failure. Blood Coagul Fibrinolysis 1992; 3: 243-7.

7 Langley PG, Hughes RD, Rolando N, Williams R. Increased elastase- $\alpha_{1}$-antitrypsin complex in fulminant hepatic failure: relationship to bacterial infection and activation of coagulation. Clin Chim Acta 1991; 200: 211-20.

8 Delers $F$, Mangeney $M$, Raffa $D$, et al. Changes in rat liver mRNA for $\alpha$-1-acid-glycoprotein, apolipoprotein E, mRNA for $\alpha-1$-acid-glycoprotein, apolipoprotein E, apolipoprotein B and beta-actin after mouse recombinant Commun 1989; 161: 81-8.
9 Ramadori G, Sipe JD, Dinarello CA, Mizel SB, Colten HR. Pretranslational modulation of acute phase hepatic protein synthesis by murine recombinant interleukin-1. f Exp Med 1985; 162: 930-42.

10 Klapproth J, Castell JV, Geiger T, Andus T, Heinrich PC. Fate and biological action of human recombinant interleukin- $1 \beta$ in the rat in vivo. Eur $\mathcal{F}$ Immunol 1989; 19: $1485-90$.

11 Geiger T, Andus T, Klapproth J, Hirano T, Kishimoto T, Heinrich PC. Induction of rat acute-phase proteins by interleukin-6 in vivo. Eur $f$ Immunol 1988; 18: 717-21.

12 Ramadori G, Van Damme J, Rieder H, Meyer zum Büschenfelde $\mathrm{KH}$. Interleukin-6, the third mediator of acute-phase reaction, modulates hepatic protein synthesis in human and mouse: comparison with interleukin-1 $\beta$ and tumor necrosis factor $\alpha$. Eur $\mathcal{F}$ Immunol 1988; 18: 1259-64.

13 Marinkovic S, Jahreis GP, Wong GG, Baumann H. IL-6 modulates the synthesis of a specific set of acute phase hepatic proteins in vivo. $f$ Immunol 1989; 142: 808-12.

14 Castell JV, Gomez-Lechon MJ, David M, Hirano T, Kishimoto T, Heinrich PC. Recombinant human interKishimoto T, Heinrich PC. Recombinant human inter-
leukin-6 (IL-6/BSF-2/HSF) regulates the synthesis of leukin-6 (IL-6/BSF-2/HSF) regulates the synthesis of acute phase protein

15 Castell JV, Gomez-Lechon MJ, David M, et al. Interleukin6 is the major regulator of acute phase protein synthesis in adult human hepatocytes. FEBS Lett 1989; 242: 237-9.

16 Castell JV, Gomez-Lechon MJ, David M, Fabra R, Trullenque R, Heinrich PC. Acute-phase response of human hepatocytes: regulation of acute-phase protein synthesis by interleukin-6. Hepatology 1990; 12: 1179-86.

17 Sheron N, Goka J, Wendon J, et al. Highly elevated plasma cytokines in fulminant hepatic failure: correlations with multiorgan failure and death. Hepatology 1990; 12: 939.

18 Shiratori Y, Moriwaki H, Kawashima Y, et al. Elevated interleukin-6 levels in sera of patients with fulminant hepatitis. Gastroenterol fpn 1991; 26: 233.

19 Muto Y, Nouri-Aria K, Meager A, Alexander GJM, Eddleston ALWF, Williams R. Enhanced tumour necrosis factor and interleukin-1 in fulminant hepatic failure. Lancet 1988; ii: 72-4.

20 Trey C, Davidson CS. The management of fulminant hepatic failure. In: Popper H, Schaffner F, eds. Progress in liver disease. Vol 3. New York: Grune \& Stratton, 1970: 282-98.

21 O'Grady JG, Alexander GJM, Hayllar KM, Williams R. Early indicators of prognosis in fulminant hepatic failure. Gastroenterlogy 1989; 97: 430-45.

22 Highton J, Hessian P. A solid phase enzyme immunoassay for C-reactive protein: Clinical value and the effect of rheumatoid factor. $\mathcal{F}$ Immunol Methods $1984 ; 68$ : 186-92.

23 Clauss A. Gerinnungsphysiologisches schnellmethode zur bestinnung des fibrinogens. Acta Haematol 1957; 17: 237-46.

24 Kushner I. The acute phase response: an overview. Methods Enzymol 1988; 163: 373-83.

25 Rolando N, Harvey F, Brahm J, et al. Bacterial infection in acute liver failure. Hepatology 1990; 11: 49-53.

26 Dofferhoff ASM, Bom VJJ, van Ingen J, et al. Bacterial endotoxin: cytokine mediators and new therapies for sepsis. New York: Wiley-Liss, 1991: 43-54.

27 Hughes RD, Lane DA, Ireland H, Langley PG, Gimson AES, Williams R. Fibrinogen derivatives and platelet activation products in acute and chronic liver disease. Clin Sci 1985; 68: 701-7.

28 Langley PG, Forbes AF, Hughes RD, Williams $R$. Thrombin-antithrombin III complex in fulminant hepatic failure: evidence for disseminated intravascular coagulafailure: evidence for disseminated intravascular coagula-
tion and relationship to outcome. Eur $\mathcal{F}$ Clin Invest 1990; 20: $627-31$.

29 Jirik FR, Podor TJ, Hirano T, et al. Bacterial lipopolysaccharide and inflammatory mediators augment IL-6 secretion by human endothelial cells. F Immunol 1989; 42: 144-7

30 Calandra T, Gerain J, Heumann D, Baumgartner JP, Glauser MP, and the Swiss Dutch J5 Immunoglobulin Study Group. High circulating levels of interleukin-6 in patients with septic shock: evolution during sepsis, nostic value, and interplay with other cytokines. Am $\mathscr{J} M e d$ 1991; 91: 23-9.

31 Castell JV, Geiger T, Gross V, et al. Plasma clearance, organ distribution and target cells of interleukin-6/hepatocyte distribution and target cells of interleukin-6/hepatocyte stimulating

32 Oka Y, Murata A, Nishijima J, et al. Circulating interleukin 6 as a useful marker for predicting postoperative complications. Cytokine 1992; 4: 298-304.

33 Ohzato $\mathrm{H}$, Yoshizaki K, Nishimoto $\mathrm{N}$, et al. Interleukin-6 as a new indicator of inflammatory status: detection of serum levels of interleukin- 6 and C-reactive protein after surgery. Surgery 1992; 111: 201-9.

34 Van Oers MHJ, Van der Heyden AAPAM, Aarden LA. Interleukin-6 (IL6) in serum and urine of renal transplant recipients. Clin Exp Immunol 1988; 71: 314-9.

35 Heath DI, Cruickshank A, Gudgeon M, Jehanli A, Shenkin A, Imrie CW. Role of interleukin- 6 in mediating the acute phase protein response and potential as an early means of peverity assessment in acute pancreatitis. Gut 1993; 34: 41-5.

36 Fong Y, Moldawer LL, Marano M, et al. Endotoxemia elicits increased circulating b1-IFN/IL-6 in man. f Immunol 1989; 142: 2321-4. 